\title{
Motivational factors for educational tourism: marketing insights
}

\author{
Ibrahim HARAZNEH \\ Middle East University, Amman, Jordan \\ iharazneh@meu.jo \\ Raad Meshall AL-TALL \\ Jadara University, Irbid, Jordan \\ altall1985@yahoo.com \\ Mohammad Fahmi AL-ZYOUD \\ Al-Ahliyya Amman University, Amman, Jordan \\ m.alzyoud@ammanu.edu.jo \\ A. Mohammed ABUBAKAR \\ Antalya Bilim University, Antalya, Turkey \\ mohammed.abubakar@antalya.edu.tr
}

\begin{abstract}
Intertwined with other structural changes, are policies to increase the number of international students to diversify tourism activities into what is known as educational tourism (edutourism). Of immediate relevance to this article is the implementation of policies and strategies to attract students from all over the world. Unfortunately, these policies are partially implemented opting out important factors, as such this article attempt to conceptualize the motivational factors associated with edu-tourism. Data garnered from foreign students in North Cyprus suggest that cost, quality, environmental, regulatory, cultural, political, safety and social factors are key factors for edu-tourism. The outcome in this study will help policy makers determine the factors that influence the choice of tertiary institutions in North Cyprus associated with a particular geodemographic setup. This will also enable policy makers to create a tailor made persuasive strategies, policies, adverts and messages to increase their market share.
\end{abstract}

Keywords: educational tourism, motivational factors, learners, international students, North Cyprus.

Please cite the article as follows: Harazneh, I., Al-Tall, R. M., Al-Zyoud, M. F. and Abubakar, A.M. (2018), "Motivational factors for educational tourism: An empirical test", Management \& Marketing. Challenges for the Knowledge Society, Vol. 13, No. 1, pp. 796-811, DOI: 10.2478/mmcks-2018-0006.

\section{Overview}

Lundberg (1972) posed the question "why do people travel?", and this paper attempts to query the motivations for educational tourism geodemographic wise.

According to Rodger (1998), educational tourism (edu-tourism) is a process by which an individual or group of individuals travel across international borders for the purpose of learning, or to engage in any form of knowledge acquisition. Individuals who travel across international borders to acquire intellectual services are popularly known as educational tourist (edu-tourists) Abubakar, Shneikat and Oday (2014). According to World Tourism Organization (2012), edu-tourists are "individuals or groups who travel to and 
stay in places outside their usual environment for more than $24 \mathrm{~h}$ and not more than one year"; with the motive to engage in learning, business, leisure and other activities.

More specifically, edu-tourism industry is expected to attract 1,070,000 students by 2017 (Ortiz, Chang and Fang, 2015), and the global spending on educational products and services is expected to increase from $\$ 4.4$ trillion in 2012 to $\$ 6.2$ trillion in 2017 (Ortiz, Chang and Fang, 2015). Similarly, Northern Cyprus educational sector generated $\$ 400$ million in 2011 (Zaman Yazarları, 2014), and this figure is expected to increase in the coming years. Many factors are taught to influence students in choosing their institution abroad. For instance, educational programs in English opens up an institution for a wider audience, and also increases their competitive advantage (Rico and Loredana, 2009). Because students are looking for new experiences, norms and future job prospects. Further, potential edu-tourists are keen to leave home, and willing to travel and experience new cultures (Blight, 1995; Mansfield, 2013).

Universities and tertiary institutions are adopting inter-nationalization strategies, to enable them attract and recruit international students, and to increase their market share (Cubillo, Cerviño and Sánchez, 2006). Drawing on pull and push factor framework, Felix and Steve (2007) suggested that pull factors from the host county perspective include: easy admission, international recognition and safe environment; and from the institution perspective the pull factors include: course availability, expertise, cost of living, cheap accommodation and future employment prospects in the labor market. Whereas push factors subsumes economic, political and host country capacity, which are contingent upon friends, family members, private agencies, media, and word-of-mouth (WOM) as noted by (Felix and Steve, 2007).

Research has shown that the reputation of countries and universities in terms of quality, marketing efforts, academic staffs, programs, academic collaborations, and technology influences students' decision in selecting a host country/institution (Mazarrol, Kemp and Savery, 1997). Geographical proximity, common language, colonial and historical ties between the home and host countries and the availability of science and technologybased programs are key factors influencing student's (Jason et al., 2011). Political interests and ties can have profound effect (Lee and Tan, 1984), more subtly through monetary aid, tuition fee waiver, merit-based scholarships and other form of assistances (Jason et al., 2011).

\section{Purpose and Contribution of the Study}

The economic value of edu-tourism and its associated societal impact have been ignored by policy makers (Ritche, 2003). The current booming of edu-tourism sector, and its market value is only expected to proliferate (Gibson, 1998; Holdnak and Holland, 1996). Tourism and More (2010) added that "edu-tourism is one of the fastest growing areas of the travel and tourism and one that is too often overlooked by tourism professionals and marketers. Researchers like Joyce (2012) have called for more research to tap important aspects of edu-tourism, and its potential contribution to development and economic growth. Without much tautology, this benefits can only be realize with a nuanced understanding of the concept (i.e., students' motives to engage in edu-tourism). A number of scholars who have attempted to identify international students' motives are presented in Table 1 . These studies investigated one or two motivational factors, thus, a frame of reference is still 
lacking, which highlights the need to conceptualize edu-tourism motivational factors for the purpose of coherency.

Table 1. Underpinned motivational factors

\begin{tabular}{|l|l|}
\hline Motivational factor & Authors \\
\hline Perceived risk e.g., discrimination \& race & (Lam, Tong and Ariffin, 2016), \\
\hline To learn a second language & (Bodycott, 2009; Counsell, 2011), \\
\hline Geographical proximity & (Soo and Elliott, 2010), \\
\hline Cultural proximity & (Counsell, 2011; Lee and Morrish, 2012), \\
\hline Reputation for high-quality educational system & (Petruzzellis and Romanazzi, 2010), \\
\hline Safety & (Anderson and Bhati, 2012), \\
\hline The need for international exposure & (Anderson and Bhati, 2012; Bodycott, 2009), \\
\hline Lack of higher education in the home country & (Bodycott, 2009; Maringe and Carter, 2007), \\
\hline Career benefits & (Counsell, 2011; Eder et al., 2010; Ivy, 2010), \\
\hline Visa procedure & (Eder et al., 2010; Urias and Yeakey, 2008), \\
\hline Price of education and living costs & (Bourke, 2000; Lam et al., 2016), \\
\hline $\begin{array}{l}\text { Policies (e.g., part-time jobs, post-graduation } \\
\text { employment or immigration opportunities) }\end{array}$ & (Ho et al., 2007; Yang, 2007), \\
\hline $\begin{array}{l}\text { Social influence (e.g., family members, friends, } \\
\text { teachers, relatives, agents \& social media) }\end{array}$ & $\begin{array}{l}\text { (Cheung et al., 2011; Ivy, 2010; Lee, 2014; } \\
\text { McCarthy et al., 2012). }\end{array}$ \\
\hline
\end{tabular}

Source: Authors' own research.

Abubakar, Shneikat and Oday, (2014) harvested the following 15 factors as edutourism motivations utilizing attribution theory and pull and push framework: accreditation, reputation, future job prospects and English as teaching medium, quality of education, failing in entrance exam in the home country, culture, new language, travel and welcoming attitudes of the locals, tuition fees and scholarships, safety and low rate of discrimination in host country, quality of life and living expenses in the host country, political instability in the home country, easy to get visa, easy admission, recognition in the home country, qualified and friendly academic staff, natural and environmental factors, lack of availability of program in the home country, closeness to the home country.

This study embrace quantitative approach to extend Abubakar et al. (2014) study which largely relied on qualitative data. Sound judgment and predictability are the shortcomings of qualitative approach, as such, this study employ quantitative method due to its objective and reliable nature. Additionally, policy makers need to be able to determine the factors that influence the choice of tertiary institutions associated with geodemographic variables. By conceptualizing these factors, policy makers will be able to create a tailor made persuasive strategies, policies, adverts and messages to increase their market share.

\section{Methodology}

\section{Research instruments}

Edu-tourism has become an important part of the tourism economy. Abubakar, Shneikat, and Oday (2014) conducted a qualitative study which answer the following question: why people study abroad in general; and also why did participants choose the current country and institution they were enrolled at. Their study came up with several motivational factors associated with edu-tourism in North Cyprus, some of these factors were highlighted in prior studies (Blight, 1995; Felix and Steve, 2007; Jason et al., 2011; Mazarrol, Kemp and Savery, 1997). Relying on these premier literatures, the current study classified the 
motivational factors into eight (8) categories namely: Cost, quality, environmental, regulatory, cultural, political, safety and social factors with sub-questions in each category as depicted in Table 1.

\section{Data collection and procedures}

One marketing psychologist, a tourism marketing consultant and two independent academicians (PhD) were contacted to provide their opinions concerning the suitability and potential bias of the measures as recommended by DeVellis (2012). All of them provided useful feedbacks which were taken into consideration prior to the main study. Then a pilot survey was conducted with 10 students, and necessary changes were made to the scale items. The survey was administered online, and the link to the survey was posted and shared via various social outlets, closed and open groups. Some faculty members also informed students to voluntarily participate in the study.

International students from the following universities namely: Eastern Mediterranean University - 1979, Girne American University - 1985, Near East University 1988, European University of Lefka - 1990, Cyprus International University - 1997, and University of Mediterranean Karpasia - 2012 randomly participated in the study, which gave each student equal chance of being selected. Although two of the aforementioned universities are public funded universities, all of them have similar mode of operation, offers similar programs and also competes in the same market.

Enrolled students were asked to voluntarily participate in the research at a convenient time, this friendly approach is known to increase response rate and data quality (Bronner and Kuijlen 2007). Overall, the survey link was active for about two months. The respondents were asked to rank edu-tourism factors according to their importance, with a five point scale ranging from (1) strongly disagree to (5) strongly agree. Socio-demographic variables such as age, gender, program, and country of origin were captured. Despite our efforts to increase audience for the project, out of 18,646 registered international students (Gundem Kibris 2015), only 2,049 participated in the study. At last only 536 usable samples were retained, as responses with missing data were discarded. Online survey response rate are usually low, moreover, the current response rate deems adequate (Cook, Heath and Thompson, 2000).

\section{Data analysis and findings \\ Profile of contributors}

Fifty nine percent of the participating students were male, and $41 \%$ were female. About $73.5 \%$ of the participating students are registered in BSc programs, $22.8 \%$ registered in higher degree programs and the rest in associate degree programs. An overwhelming number of the students $51.1 \%$ were between 21 and 25 years old, $24.3 \%$ were less than 20 years old, 13.4\% were between 26 and 30 years old, $8 \%$ were between 31 and 35 years old and the rest were above 35 . In regard to nationality of the students, $1.3 \%$ were from Algeria, 1.9\% from Egypt, 0.6\% from France, 0.4\% from Germany, 1.9\% from Ghana, 17.2\% from Iran, 9.3\% from Iraq, 8.8\% from Jordan, 8\% from Libya, 14.6\% from Nigeria, 2.1\% from Pakistan, 4.9\% from Palestine, 4.3\% from Russia, 1.7\% from Saudi Arabia, 0.9\% from South Africa, $11 \%$ from Syria, 3.2\% from Tajikistan, $0.7 \%$ from Tunisia, $0.4 \%$ from the United States, 0.9\% from Zambia, and 3.7\% from Zimbabwe. 

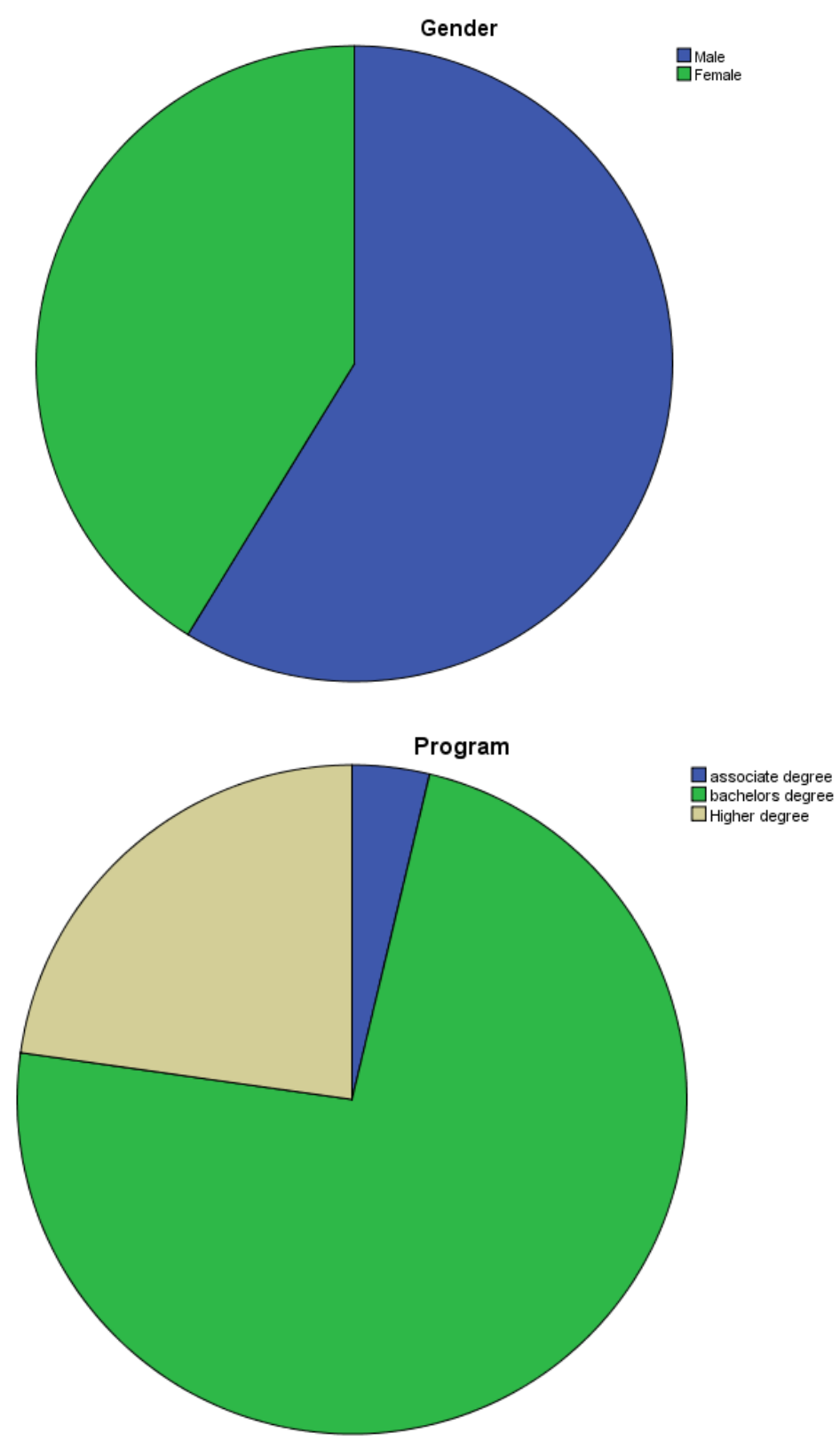

Figure 1. Gender and academic program distribution

Source: Authors' own research. 


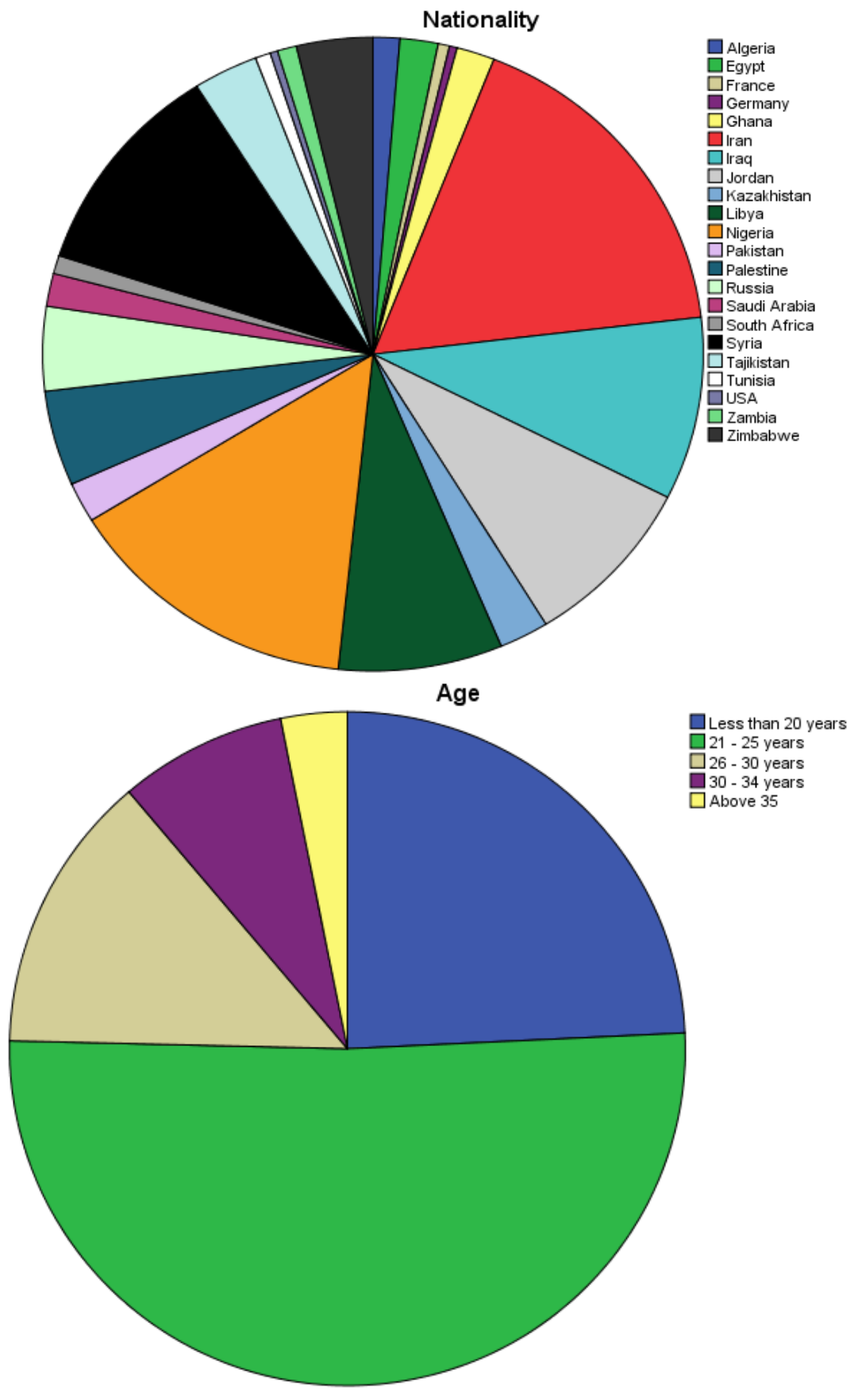

Figure 2. Students' age and nationality distribution

Source: Authors' own research. 


\section{Motivations of contributors}

The retained responses were subjected to exploratory factor analyses (EFA) utilizing IBM SPSS version 22. All the scale items fit into their respective factor; and the standardized factor loadings were reasonably above the benchmark of .50 as suggested by (Hair et al., 1998). Cronbach's alphas for all factors exceeded .70, and the Eigen values were also greater than 1 . Mean and standard deviation of the measures were within an acceptable range. For more details see Table 2.

Table 2. Psychometrics Properties of the Measures

\begin{tabular}{|c|c|c|}
\hline Scale items & Loadings & Mean (S.D) \\
\hline \multicolumn{3}{|l|}{ Cost factor $(\alpha=.89 ;$ Eigen value $=1.8 ;$ Variance $=6.9 \%)$} \\
\hline Tuition fees and scholarships & .88 & $3.78(1.13)$ \\
\hline Living expenses in the host country & .83 & $3.90(.998)$ \\
\hline \multicolumn{3}{|l|}{ Quality factor $(\alpha=.82 ;$ Eigen value $=2.8$; Variance $=10.8 \%)$} \\
\hline Quality of education & .68 & $4.08(.908)$ \\
\hline Quality of life & .74 & $3.40(1.14)$ \\
\hline Qualified and friendly academic staff & .79 & $3.45(1.33)$ \\
\hline Availability of labs and research instruments & .82 & $3.30(1.43)$ \\
\hline \multicolumn{3}{|l|}{ Environmental factor $(\alpha=.95 ;$ Eigen value $=1.9 ;$ Variance $=7.6 \%)$} \\
\hline Natural and environmental factors e.g., landscape, sea \& beach & .89 & $3.73(1.07)$ \\
\hline Favorable climate and weather condition & .92 & $3.77(1.05)$ \\
\hline \multicolumn{3}{|l|}{ Regulatory factor $(\alpha=.94 ;$ Eigen value $=4.0$; Variance $=16.2 \%)$} \\
\hline Recognition in the home country & .86 & $3.49(1.41)$ \\
\hline Failing entrance exam in home country & .89 & $3.66(1.23)$ \\
\hline Lack of available program in home country & .91 & $3.63(1.20)$ \\
\hline Easy to get visa/visa free & .84 & $3.35(1.44)$ \\
\hline Easy admission & .93 & $3.55(1.23)$ \\
\hline \multicolumn{3}{|l|}{ Cultural factor $(\alpha=.77$; Eigen value $=2.4 ;$ Variance $=9.3 \%)$} \\
\hline Closeness to the home country (proximity) & .74 & $2.67(1.25)$ \\
\hline Historical or colonial ties. & .69 & $2.57(1.15)$ \\
\hline New language, common language, and travel & .74 & $2.44(1.32)$ \\
\hline Welcoming attitudes of the locals & .73 & $2.82(1.29)$ \\
\hline \multicolumn{3}{|l|}{ Political $(\alpha=.97 ;$ Eigen value =3.0; Variance $=11.6 \%)$} \\
\hline Political instability in home country & .94 & $3.58(1.11)$ \\
\hline Political stability in host country & .93 & $3.45(1.15)$ \\
\hline Political ties with the host country & .96 & $3.51(1.12)$ \\
\hline \multicolumn{3}{|l|}{ Safety factor $(\alpha=.62 ;$ Eigen value $=1.7 ;$ Variance $=6.4 \%)$} \\
\hline Safety and low rate of discrimination in host country & .76 & $3.38(1.20)$ \\
\hline Institutionalized legal processes & .74 & $3.17(1.18)$ \\
\hline \multicolumn{3}{|l|}{ Social factor $(\alpha=.79 ;$ Eigen value $=2.6$; Variance $=9.9 \%)$} \\
\hline Accreditation and reputation of the country \& its institutions & .82 & $3.59(1.20)$ \\
\hline Future job prospects & .71 & $3.96(.974)$ \\
\hline English as teaching medium & .57 & $3.97(1.07)$ \\
\hline Referrals from friends, family members and social media & .78 & $3.94(1.00)$ \\
\hline
\end{tabular}

Regulatory factor emerged as the most important factor by explaining $16.2 \%$ of the variance, political factor follow up by explaining $11.6 \%$ of the variance. Quality factor was third in row by explaining $10.8 \%$ of variance, social factor was fourth in row as it explained $9.9 \%$ of the variance. Cultural factor followed up by explaining $9.3 \%$ of the variance. Subsequently, environmental factor, cost factor and safety factor 
followed up respectively. See Table 2 for further details; based on this outcomes we came up with the conceptual model in figure 3.

Antecedents

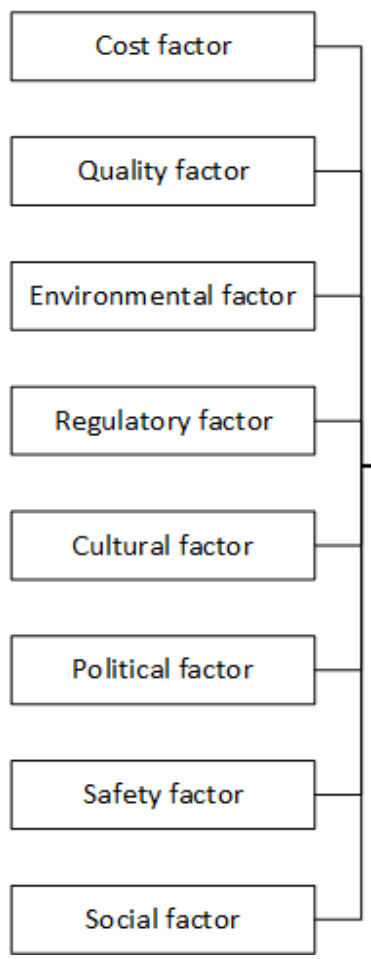

Contextual variables

Edu-tourism motivations

Figure 3. Conceptual model

Source: Authors' own research.

Next, the association of the contributor's profiles and their motivations were analyzed in IBM SPSS version 22, where motivations were categorize as endogenous variables and socio-demographics as exogenous variables. Geodemographic analysis presents an interesting alternative, particularly because it can also be a powerful device for implementing policy (Tonks and Farr, 1995). According to Tonks and Farr (1995), the merit of using geo-demographics is the fine level analysis which become possible and the avoidance of methodological problems. Significance of each relationship was evaluated using Kruskal-Wallis Test. The results in Table 3 shows that there is a variance for gender. That is quality factor, environmental factor and safety factor were found to be important for female international students in choosing a university abroad. 
Table 3. Kruskal-Wallis Test - Gender

\begin{tabular}{llllll}
\hline Factors & $\begin{array}{l}(\boldsymbol{\mu}) \\
\text { Male }\end{array}$ & $\begin{array}{l}(\boldsymbol{\mu}) \\
\text { Female }\end{array}$ & $\boldsymbol{X}^{\mathbf{2}}(\boldsymbol{d} \boldsymbol{f})$ & $\boldsymbol{p}$ & decision \\
\hline & & & & & \\
Cost factor & 265 & 273 & $.360(1)$ & .546 & No variance \\
Quality factor & 256 & $\mathbf{2 8 7}$ & $5.21(1)$ & .022 & Female \\
Environment factor & 252 & $\mathbf{2 9 3}$ & $9.76(1)$ & .002 & Female \\
Regulatory factor & 263 & 277 & $1.07(1)$ & .301 & No variance \\
Cultural factor & 262 & 278 & $1.44(1)$ & .230 & No variance \\
Political factor & 271 & 265 & $.159(1)$ & .690 & No variance \\
Safety factor & 251 & $\mathbf{2 9 3}$ & $9.50(1)$ & .002 & Female \\
Social factor & 261 & 278 & $1.30(1)$ & .255 & No variance \\
\hline
\end{tabular}

Notes: $\mathrm{X}^{2}$, chi-square; df, degree of freedom; $\mu$, mean.

Source: Authors' own research.

The registered program by participating students in Table 4 show significant differences in the cost, cultural, political, safety, and social domain. Similarly, participating students age in Table 5 show significant differences in the cost, quality, regulatory, cultural, political, and safety domain.

Table 4. Kruskal-Wallis Test - Program

\begin{tabular}{|c|c|c|c|c|c|c|}
\hline Factors & $\begin{array}{l}(\mu) \\
\text { A.S }\end{array}$ & $\begin{array}{l}(\mu) \\
\text { BSc }\end{array}$ & $\begin{array}{l}(\mu) \\
\text { Higher }\end{array}$ & $X^{2}(d f)$ & $p$ & decision \\
\hline Cost factor & 220 & 288 & 213 & $27(2)$ & .000 & variance exist \\
\hline Quality factor & 212 & 266 & 284 & $4(2)$ & .129 & No variance \\
\hline Environment factor & 299 & 262 & 284 & $3(2)$ & .258 & No variance \\
\hline Regulatory factor & 243 & 278 & 244 & $5(2)$ & .075 & No variance \\
\hline Cultural factor & 365 & 267 & 257 & $9(2)$ & .014 & variance exist \\
\hline Political factor & 226 & 289 & 208 & $29(2)$ & .000 & variance exist \\
\hline Safety factor & 301 & 288 & 200 & $32(2)$ & .000 & variance exist \\
\hline Social factor & 234 & 283 & 227 & $13(2)$ & .001 & variance exist \\
\hline
\end{tabular}

Notes: $\mathrm{X}^{2}$, chi-square; df, degree of freedom; $\mu$, mean; A.S, associate degree; BSc, bachelor's degree, higher, (Master degree, Doctorate degree)

Source: Authors' own research.

Table 5. Kruskal-Wallis Test - Age

\begin{tabular}{llllllrll}
\hline Factors & $(\boldsymbol{\mu})$ & $(\boldsymbol{\mu})$ & $(\boldsymbol{\mu})$ & $(\boldsymbol{\mu})$ & $(\boldsymbol{\mu})$ & & & \\
& $<=\mathbf{2 0}$ & $\mathbf{2 1 - 2 5}$ & $\mathbf{2 6 - 3 0}$ & $\mathbf{3 1 - 3 5}$ & $\boldsymbol{> 3 5}$ & $\boldsymbol{X}^{\mathbf{2}}(\boldsymbol{d} \boldsymbol{f})$ & $\boldsymbol{p}$ & decision \\
Cost factor & & & & & & & & \\
Quality factor & 265 & $\mathbf{2 8 8}$ & 197 & $\mathbf{2 8 1}$ & 259 & $22(4)$ & .000 & variance exist \\
Environment factor & 238 & 260 & $\mathbf{2 9 5}$ & $\mathbf{3 6 0}$ & $\mathbf{2 8 9}$ & $23(4)$ & .000 & variance exist \\
Regulatory factor & 231 & 261 & 294 & 278 & 186 & $9(4)$ & .070 & No variance \\
Cultural factor & $\mathbf{2 8 1}$ & 267 & $\mathbf{2 8 6}$ & 182 & $\mathbf{3 3 6}$ & $32(4)$ & .000 & variance exist \\
Political factor & 231 & $\mathbf{2 9 4}$ & 250 & 197 & $\mathbf{3 4 5}$ & $15(4)$ & .006 & variance exist \\
Safety factor & $\mathbf{3 1 5}$ & $\mathbf{2 7 5}$ & 247 & 198 & 86 & $27(4)$ & .000 & variance exist \\
Social factor & 251 & 282 & 249 & 245 & 325 & $9(4)$ & .000 & variance exist \\
\hline
\end{tabular}

Notes: $\mathrm{X}^{2}$, chi-square; $\mathrm{df}$, degree of freedom; $\mu$, mean

Source: Authors' own research. 


\section{Discussion}

It is important to identify and monitor the factors affecting the operations of tertiary institutions. The number of scholarships on the motivational factors for foreign students' on enrollment decision for higher education are comparatively low, this study contributes in this aspect. Changes in the composition of students from different geographical location is of concern, and this can be monitor using a number of indicators. Of these cost, quality, environmental, regulatory, cultural, political, safety and social indicators surfaced as accepted measures for edu-tourism motivations. The result of this study depicts a difference between male and female students on issues related to quality, environmental and safety factors. Eagly (1987) social-role theory offers a useful perspective to explain these difference. Female students ranked the aforementioned factors primarily due to their communal nature as oppose to male students with agentic nature (Eagly and Wood, 1991). Based on the findings of this study, it seems plausible to note that female students are probably more inclined to choose safe cities, value educational quality and natural environment, they also tend act more ethically and abide by the law (Roxas and Stoneback, 2004). This is because of the deep-rooted traits such as "care" often associated with females.

The results of the Kruskal-Wallis test performed on the enrolled program revealed that cost, cultural, political, safety, and social factors emerged as important indicators. The findings revealed that cost, political and social factors are important indicators for students enrolled in a bachelor's degree program. As a matter of fact, the attention given to cost, social and political factors related to bachelor's degree are as a result of pressure in the labor market. It is important to note that students want to study at a lower cost, and in a country that is politically stable and correct. Such students often possess higher level of global mindedness compared to other learners (McGladdery and Lubbe, 2017) and are more likely to get hired by international firms. In similar vein, social referrals from friends, relatives and social circles seems to be a vital motivator as it reduce students' perceptions of risk (Lam et al., 2016). Moreover, political ties with host country is important in terms of ideology and policy. Henceforth, marketers in the educational sector should consider and blend this outcome in their promotional strategies.

On the other hand, cultural and safety factors emerged as important indicators for students enrolled in associate degree programs. The nature and type of the available associate degree programs offers a useful perspective to explain these outcome, because most of them are culturally related (i.e., gastronomy, tourism and hospitality management etc.). Learners who want to be more socially and environmentally responsible young people often value cultural and safety factors, because edu-tourism "contribute to cultural integration" and is "a force for fighting xenophobia, ethnocentrism and cultural misunderstandings" (Smith, 2013, p. 5). Safety factor is important because it reduces the anxiety arising from the lack of security, which is the main risk perceived by international students. Moreover, terrorist attacks and local crimes may cause students in all programs to be wary of a certain destination (Adam, 2015).

The results highlight that students between 21 and 25, and 31 and 35 years hold similar opinions on cost factor. In particular students within this age group are more likely to be enrolled in bachelors and/or higher degree programs, this shows

Vol. 13, No. 1, Spring, pp. 796-811, ISSN 1842-0206 | Management \& Marketing. Challenges for the Knowledge Society 
that cost factor is an important factor prior enrollment. This outcome validates the findings of Lam et al. (2016) in Malaysia. The authors found that the price of education and cost of living influence decisions of international students, their sample has similar profile in terms of age with the current study. Next, we uncover that for students within the following age groups: 26 and 30, 31 and 35, and above 35, quality factor seems to be important. A plausible explanation for this finding is that learners in this age groups are mostly enrolled in masters or doctorate degree programs, as such, it is logical for them to seek quality education for their professional and academic careers. The present outcome is consistent with competition-based view, that is older students have higher expectation from their institutions (Akareem and Hossain, 2012), because with increased maturity, students start to understand that they need to add value, in addition to an acceptable result and continuously improve those added values for a successful job or career (Akareem and Hossain, 2012; 2016; Bailey et al., 1999).

Regulatory factor was significant for students in the following age groups: 21 and 25, 26 and 30, and above 35 years old. Cultural factor emerge as an important factor for students who are less than 20, and above 35 years. Richards (2011) elaborates further on the experiential nature of edu-tourism, moreover, individuals in this age group are mostly looking for new experiences. McGladdery and Lubbe (2017) utilized experiential learning theory to interpret how edu-tourist experiences can be develop to ensure the occurrence of global learning. Paige and Vande Berg (2012, p. 37) added that the most predictive measure of intercultural development amongst international university students was "guided reflection on the students' cultural experience". In similar fashion to cost factor, the results highlighted that students in the age group between 21 and 25, and 31 and 35 have similar opinions on political factor. Safety factor was important for students in the following age groups: less than 20, and between 21 and 25 years old. This present finding is logical given the age and the limited life experience of learners in these group.

\section{Conclusion}

To wrap up, this article found that foreign students' motivations to study abroad include cost, quality, environmental, regulatory, cultural, political, safety and social factors. Demographic variables such as gender, age and program act as contextual factors for the aforementioned motivational factors. Cost of leaving, scholarships and tuition fee were conceptualize under cost factor. Moreover, motives for students leaving their country include academic reputation, personal, academic and professional development were conceptualize as quality factor. Factors like climate of the location and spiritual atmosphere were grouped under environmental factor. Regulatory factors was conceptualize as policies e.g., visa, immigration, and enrollment. Cultural ties, new language, proximity, seeking an international experience and travel were categorize as cultural factor. Political factors subsumes political ties and policies in host and home counties. Issues like discrimination, rule of law and racism were categorize and validated as safety factors. Social factor include student's reference group and social network (e.g., interpersonal information sources and e-WOM). 
All-inclusive, the results of this paper highlights vital managerial implications for marketing edu-tourism destinations. They can help marketers to design and promote strategies that would attract foreign students. The findings of this study suggest that tertiary institutions should be able to capitalize on this factors in promoting their institutions abroad. Moreover, another implication of this findings for practice illustrate that higher institutions need to promote their internationalization policies, which in turn promotes international student mobility. Additionally, these findings suggest that edu-tourists have different expectations and needs, hence, related industries and the policymakers need to develop a thorough understanding of the expectation of these distinct tourist groups to establish their marketing strategies. Overall, this paper also provide answers to Lundberg $(1971,1972)$ question "why do people travel?" from edu-tourism perspective. As predicted in the omnibus model for edu-tourism motivations were all significant, the results are informative, indicating that geodemographic is an important component to consider in future research. It is possible that the lack of significant relationships for some factor in respect to a group was simply a function of insufficient power to detect effects, rather than an actual functional difference between groups. This relationship warrants attention in future research to help clarify the pattern of relationships through replications in other countries, the use rigorous analysis and larger sample size.

\section{References}

Abubakar, A. M., Shneikat, B.H.T. and Oday, A. (2014), "Motivational factors for educational tourism: A case study in Northern Cyprus", Tourism Management Perspectives, Vol. 11, No. 1, pp. 58-62. https://doi.org/10.1016/j.tmp.2014.04.002.

Adam, I. (2015), "Backpackers' risk perceptions and risk reduction strategies in Ghana”, Tourism Management, Vol. 49, No. 1, pp. 99-108. https://doi.org/10.1016/j.tourman.2015.02.016

Akareem, H. S. and Hossain, S. S. (2012), "Perception of education quality in private universities of Bangladesh: A study from students' perspective", Journal of Marketing for Higher Education, Vol. 22, No.1, pp. 11-33.

DOI: $10.1080 / 08841241.2012 .705792$

Akareem, H. S. and Hossain, S. S. (2016), "Determinants of education quality: what makes students' perception different?", Open Review of Educational Research, Vol. 3, No. 1, pp. 52-67. DOI: 10.1080/23265507.2016.1155167

Anderson, R. and Bhati, A. (2012), "Factors influencing Indian student's choice of overseas study destination", International Journal of Innovative Interdisciplinary Research, Vol. 1, No. 2, pp. 66-76. https://doi.org/10.1016/j.sbspro.2012.05.365

Bailey, A. R., Chow, C. W. and Haddad, K. M. (1999), "Continuous improvement in business education: Insights from the for-profit sector and business school deans", Journal of Education for Business, Vol. 74, No. 3, pp. 165-180. DOI:10.1080/08832329909601681

Blight, D. (1995), International Education: Australia's Potential Demand and Supply. IDP Education Australia, Canberra.

Bronner, A. E. and Kuijlen, T. (2007), "The Live or Digital Interviewer: A Comparison Vol. 13, No. 1, Spring, pp. 796-811, ISSN 1842-0206 | Management \& Marketing. Challenges for the Knowledge Society 
between CASI, CAPI and CATI with Respect to Differences in Response Behavior", International Journal of Market Research, Vol. 49, No. 2, pp. 167-190. http://hdl.handle.net/11245/1.279935

Bodycott, P. (2009), "Choosing a higher education study abroad destination: What mainland Chinese parents and students rate as important", Journal of Research in International Education, Vol. 8, No. 3, pp. 349-373.

DOI: $10.1177 / 1475240909345818$

Bourke, A. (2000), "A model of the determinants of international trade in higher education", The Service Industries Journal, Vol. 20, No. 1, pp. 110-138. https://doi.org/10.1080/02642060000000007

Cheung, A., Yuen, T., Yuen, C. and Cheng, Y. C. (2011), "Strategies and policies for Hong Kong's higher education in Asian markets", International Journal of Educational Management, Vol. 25, No. 2, pp. 144-163. https://doi.org/10.1108/09513541111107579

Cook, C., Heath, F. and Thompson, R.L. (2000), "A meta-analysis of response rates in web or internet-based surveys", Educational and Psychological Measurement, Vol. 60, No. 6, pp. 821-836. https://doi.org/10.1177/00131640021970934

Counsell, D. (2011), "Chinese students abroad: Why they choose the UK and how they see their future", China: An International Journal, Vol. 9, No. 1, pp. 48-71. https://doi.org/10.1142/S0219747211000045

Cubillo, J.M., Joaquín Sánchez, J. and Cerviño, J. (2006), “International students' decision-making process", International Journal of Educational Management, Vol. 20, No. 2, pp. 101-115. https://doi.org/10.1108/09513540610646091

DeVellis, R. F. (2012), Scale development: Theory and applications (3rd ed.). Thousand Oaks, CA: Sage Publications, Inc

Eagly, A.H. (1987), Sex Differences in Social Behavior: A Social Role Interpretation, Erlbaum, Hillsdale, NJ.

Eagly, A. H. and Wood, W. (1991), "Explaining sex differences in social behavior: A meta-analytic perspective", Personality and Social Psychology Bulletin, Vol. 17, No.1, pp. 306-331. https://doi.org/10.1177/0146167291173011

Eder, J., Smith, W. and Pitts, R. (2010), “Exploring factors influencing student study abroad destination choice", Journal of Teaching in Travel \& Tourism, Vol. 10, No. 3, pp. 232-250. https://doi.org/10.1080/15313220.2010.503534

Felix, M. and Steve, C. (2007), "International students' motivations for studying in UK HE: Insights into the choice and decision making of African students", International Journal of Educational Management, Vol. 21, No. 6, pp. 459 - 475. https://doi.org/10.1108/09513540710780000

Gibson, H. (1998), "The educational tourist", Journal of Physical Education, Recreation \& Dance, Vol. 69, No. 4, pp. 32-34. https://doi.org/10.1080/07303084.1998.10605533

Gundem Kibris (2015), “KKTC Universiteleri”, available at: gundemkibris.com/kktcuniversitelerine-70-bin-ogrenci-kayit-yaptirdi-95385.htm. (Accessed February 2016).

Ho, E., Li, W., Cooper, J. and Holmes, P. (2007), The experiences of Chinese international students in New Zealand. New Zealand: Migration Research Group \& University of Waikato 
Holdnak, A. and Holland, S. (1996), “Edu-tourism: Vacationing to learn”, Parks and Recreation, Vol. 31, No. 9, pp. 72-75.

Ivy, J. (2010), “Choosing futures: Influence of ethnic origin in university choice”, International Journal of Educational Management, Vol. 24, No. 5, pp. 391-403. https://doi.org/10.1108/09513541011055965

Jason, M.S.L., Ahmad, A.M.A. and Azhar, H.A. (2011), "Edu-tourism: Exploring the PushPull Factors in Selecting a University", International Journal of Business and Society, Vol. 12, No. 1, pp. 63-78.

Joyce, P. (2012), “Educational tourism empowerment: Implications for flexible learning and digital equity", Pittman. Journal of Tourism Hospitality, Vol. 1, No. 4, pp. 1-119, DOI: 10.4172/2167-0269.1000e119

Lam, J.M.S., Tong, D.Y.K. and Ariffin, A.A.M. (2016), “Exploring Perceived Risk and Risk Reduction Strategies in the Pursuit of Higher Education Abroad: A Case of International Students in Malaysia", Journal of Studies in International

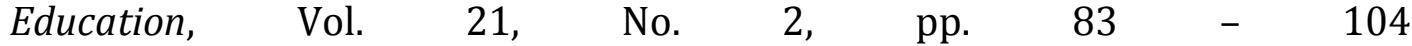
https://doi.org/10.1177/1028315316662980

Lee, C. (2014), "An investigation of factors determining the study abroad destination choice: A case study of Taiwan", Journal of Studies in International Education, Vol. 18, No. 4, pp. 362-381. DOI: 10.1177/102831531349706

Lee, C. and Morrish, S. (2012), "Cultural values and higher education choices: Chinese Families”, Australasian Marketing Journal, Vol. 20, No. 1, pp. 59-64. https://doi.org/10.1016/j.ausmj.2011.10.015

Lee, K.H. and Tan, J.P. (1984), "The international flow of third level lesser developed country students to developed countries: Determinants and implications", Higher Education, Vol. 13, No. 1, pp. 687-707. https://doi.org/10.1007/BF00137020

Lundberg, D.E. (1971), "Why Tourists Travel. The Cornell Hotel and Restaurant", Administration Quarterly, Vol. 26, No. 1, pp. 75-81. https://doi.org/10.1177/001088047101100413

Lundberg, D.E. (1972), "The Tourist Business. Donald E. Lundberg.

Institutions/Volume Feeding Management Books, Cahners Publishing Company, 5 South Wabash Avenue, Chicago, Illinois 60603. 1972. 276p", Journal of Travel Research, Vol. 11, No. 1, pp. 15 - 15. https://doi.org/10.1177/004728757201100158

Mansfield, C. (2013), “JTCaP Tourism Consumption”, Online Journal Tourism consumption.org.

Maringe, F. and Carter, S. (2007), “International students' motivations for studying in UK HE”, International Journal of Educational Management, Vol. 21, No. 6, pp. 459-475. https://doi.org/10.1108/09513540710780000

Mazarrol, T., Kemp, S. and Savery, L. (1997), "International students who choose not to study in Australia: An examination of Taiwan and Indonesia", Australian International Education Foundation, Canberra.

McCarthy, E., Sen, A. and Fox Garrity, B. (2012), Factors that influence Canadian students' choice of higher education institutions in the United States", Business Education and Accreditation, Vol. 4, No. 2, pp. 85-95. https://ssrn.com/abstract=2144995 
McGladdery, C.A. and Lubbe, B.A. (2017), "International educational tourism: Does it foster global learning? A survey of South African high school learners", Tourism $\begin{array}{lllll}\text { Management, } & \text { Vol. } & 62, & \text { No.1, } & \text { pp. }\end{array}$ https://doi.org/10.1016/j.tourman.2017.05.004.

Ortiz, A., Li Chang, L. and Yuanyuan Fang, Y. (2015), International Student Mobility Trends 2015: An Economic Perspective. Available at: http://wenr.wes.org/2015/02/international-student-mobility-trends-2015an-economic-perspective/ (Accessed February 2016).

Paige, R. M. and Vande Berg, M. (2012), "Why students are not learning abroad", In M. Vande Berg, R. M. Paige, \& K. H. Lou (Eds.), Student learning abroad: What are students are learning, what they're not, and what we can do about it (pp. 29-60).

Petruzzellis, L. and Romanazzi, S. (2010), "Educational value: How students choose university", International Journal of Educational Management, Vol. 24, No. 2, pp. 139-158. https://doi.org/10.1108/09513541011020954

Ritche, B W. (2003), Managing Educational Tourism. Channel View Publications.

Ritchie, B., Carr, N. and Cooper, C. (2003), Managing Educational Tourism. Clevedon: Channel View Publications.

Richards, G. (2011), Cultural tourism trends in Europe: A context for the development of cultural routes. In K. Khovanova-Rubicondo (Ed.), Impact of European cultural routes on SMEs' innovation and competitiveness. (pp. 21-39). Strasbourg: Council of Europe Publishing.

Rico, M. and Loredana, P. (2009), "Higher tourism education in English -where and why?", Tourism Review, Vol. 64, No. 1, pp. 48-58. https://doi.org/10.1108/16605370910948858

Rodger, D. (1998), "Leisure, learning, and travel", Journal of Physical Education Recreation \& Dance, Vol. 69, No. 4, pp. 28-31. https://doi.org/10.1080/07303084.1998.10605532

Roxas, M.L. and Stoneback, J.Y. (2004), "The importance of gender across cultures in ethical decision-making", Journal of Business Ethics, Vol. 50, No. 2, pp. 149-165. https://doi.org/10.1023/B:BUSI.0000022127.51047.ef

Smith, A. (2013), "The role of educational tourism in raising academic standards", African Journal of Hospitality, Tourism and Leisure, Vol. 2, No. 3, pp. 1-7.

Soo, K. and Elliott, C. (2010), "Does price matter? Overseas students in UK higher education", Economics of Education Review, Vol. 29, No. 4, pp. 553-565. https://doi.org/10.1016/j.econedurev.2009.10.016

Tonks, D.G. and Farr, M. (1995), "Market segments for higher education", Marketing Intelligence \& Planning, Vol. 13, No. 4, pp. 24 - 33

Tourism and More (2010), "Educational Tourism", available at: http://www.tourismandmore.com/tidbits/educational-tourism/ (Accessed May, 2016)

Urias, D. and Yeakey, C. (2008), "Analysis of the U.S. student visa system: Misperceptions, barriers, and consequences", Journal of Studies in International Education, Vol. 13, No. 1, pp. 72-109. https://doi.org/10.1177/1028315307308135

World Tourism Organization (2012), "World Tourism Organization", available at: http://themis.unwto.org/ (Accessed April, 2012). 
Yang, M. (2007), "What attracts mainland Chinese students to Australian higher education?", Studies in Learning, Evaluation, Innovation and Development, Vol. 4, No. 2, pp. 1-12. http://hdl.cqu.edu.au/10018/5964

Zaman Yazarları (2014), "Zaman Yazarları", available at: zaman.com.tr (Accessed February 2016). 